\title{
Responding to the Call of Professionalism
}

\author{
MARK G. KUCZEWSKI
}

This special section deals with the new professionalism movement. The interest in the term "professionalism" has been growing steadily in medicine, and the word now seems to be everywhere. However, bioethicists have lagged behind our colleagues in medicine and nursing in explicitly contributing to this movement. This special section adds to the effort to catch up. ${ }^{1}$

Ethicists who came to work in medical centers have debated what we should call our departments and centers (e.g., medical ethics, biomedical ethics, healthcare ethics, medical humanities) and ourselves (e.g., ethicists, medical ethicists, clinical ethicists) for the past 15 years. The terms "bioethics" and "bioethicists" have generally garnered the greatest allegiance because of their open-endedness and flexibility. As a result, we relegated the terms "professional ethics" and "professionalism" to our colleagues in the traditional philosophy and social science departments, and these words came to signify the "ethics across the curriculum" movement that has swept undergraduate campuses. This has recently changed.

Many of the business and organizational issues that have concerned bioethicists for the past decade have become so widespread that they are now of concern to virtually all healthcare professionals, even those who would never consider consulting a bioethicist. Similarly, the increased scru- tiny of the medical profession from a variety of sectors of our society-such as the popular media, the legal profession, policymakers, and consumer groups-has led to more concern with aspects of physician behavior that have traditionally been neglected. Such issues include mistreatment of medical students by their mentors, overworking house staff, and the failure to disclose mistakes to patients. These issues are now on the agenda. However, they do not always bring to mind the term "ethics."

Professionalism has somehow captured the imagination of the medical and nursing professions as more accurately reflecting their concerns and the kind of answers they seek. We have seen a growing number of popular books by physicians regarding the human dimensions of medical practice ${ }^{2,3}$ and a concern with oaths ${ }^{4-6}$ and codes of ethics. ${ }^{7}$ The common denominator seems to be a desire by healthcare professionals to find personal, moral, and spiritual moorings as they are buffeted about by the winds of change. It is natural that "ethics" does not sound like what they are seeking. They are looking to renew their commitment to their profession, to become who they set out to be when they answered their calling.

Of course, the proximate cause of the flurry of articles on professionalism in medicine is the new competencies set forth by the Accreditation 
Council on Graduate Medical Education (ACGME). However, the attention these standards have captured clearly draws on the momentum of the new professionalism movement. Nevertheless, these competencies have brought us to a watershed moment in residency, and by extension, in medical education. Bioethicists must not let this moment slip through their fingers.

David Doukas details how the ACGME standards build on previous efforts by the American Medical Association. He points out that these competencies direct us to the character of the physicians we are training and challenge us to make virtue ethics operative. Patricia Surdyk confirms Doukas's intuition that the ACGME is focusing on character and highlights some ways that bioethicists can contribute to this orientation. My Loyola colleagues and I recount the principles that have guided the Stritch School of Medicine (Loyola University Chicago) in our professionalism efforts. We argue that the instantiation of these principles should be a standard by which professionalism curricula are evaluated. Gregory Larkin examines the role of the mentor in the professional development of aspiring physicians and makes a variety of practical suggestions for fostering mentorship. Finally, Julia Connelly examines sev- eral of the unquestioned aspects of our ideal of medical professionals and concludes that professional responsibility may not be about reviving the medical profession but will require that professionals place the interests of society ahead of the profession.

\section{Notes}

1. Bioethicists have sporadically contributed to the new professionalism movement, mainly in tandem with other medical educators. For instance, see: Wear D, Bickel J. Educating for Professionalism: Creating a Culture of Humanism in Medical Education. Iowa City: University of Iowa; 2000.

2. Nuland SB. How We Die: Reflections on Life's Final Chapter. New York: Vintage Books; 1995.

3. Gawande A. Complications: A Surgeon's Notes on an Imperfect Science. New York: Metropolitan Books; 2002.

4. Miles SH. Grand Rounds with Hippocrates: Medical Ethics and the Oath. New York: Oxford University Press, forthcoming.

5. Wear A, Geyer-Kordesch J, French R. Doctors and Ethics: The Historical Setting of Professional Ethics. Amsterdam: Rodopi; 1993.

6. Jouanna J, DeBevoise MB (trans.) Hippocrates. Baltimore, Md.: Johns Hopkins University Press; 1999.

7. See, for instance, the revised codes of ethics of the American Nurses Association (available at: http:/ / www.nursingworld.org/ethics / code/ethicscode150.htm) and the American Medical Association (available at: http:// www.ama-assn.org/ama/pub/category/2503. html). 